in the EU integration process, in order not to risk losing its leverage over Pristina. For this reason, the EU should finally provide a visa roadmap for Kosovo - not in order to lower the requirements for visa liberalisation, but in order to provide Pristina with clear guidelines for reforms. A visa roadmap would not only make the authorities more accountable in cases of shortcomings and lacking effort in the reform process; it would also send the message to the Kosovars that they too have something to gain if they work for it.
Overall, the EU needs to finally develop a more coherent and credible strategy for Kosovo in order to exercise determined leadership and live up to the responsibility it has assumed. If there is an actor that, together with its partners, has the political means to assert influence over both parties, it is the EU with its membership perspective and SAP instruments. If, however, the EU fails to find a coherent approach and finally exercise determined leadership, it will run the risk of further losing its grip on Kosovo.

\title{
Stabilization without Europeanization: Electoral Reforms in Albania
}

\author{
Judith Hoffmann*
}

\begin{abstract}
The paper looks at a challenging domestic environment for Europeanization by analysing electoral reforms in Albania. Free and fair elections have been part of the EU's political conditionality for integrating Southeast Europe since the 1990s. However, even though electoral reform remained high on the political agenda in Albania, progress in accomplishing free and fair elections was only partly achieved. Domestic political elites instrumentalised the electoral reform with the aim of getting control over state resources without consolidation democratic structures. The case of Albania shows the limits of Europeanization in transforming the institutional environment in the context of Southeast Europe.
\end{abstract}

Keywords: Europeanization, Albania, democracy, electoral reforms, political actors

Europäisierung, Albanien, Demokratie, Wahlreform, politische Akteure

\section{Introduction}

$\mathrm{R}$ esearch on post-socialist transition, by and large, regards the impact of external actors, particularly by the $\mathrm{EU}$, as successful in terms of its transfer of European norms and institutions to Central and Eastern Europe (CEE). While this perspective might hold true for the first wave of $\mathrm{EU}$ enlargement to the CEE transition countries, the effectiveness of this influence is much less obvious for the candidate and potential candidate countries in Southeast Europe (SEE) (Elbasani 2011; Grabbe 2001, 2003; Schimmelfennig/Sedelmeier 2002, 2005, 2008). Despite a growing literature, it is still not very well understood how those domestic actors strategically incorporate international norms into their local political agendas. The paper looks at the challenging environment for Europeanization in SEE analysing the area of electoral reforms in Albania.

The conduct of free and fair elections is widely seen as a minimum criterion for democracy in the transition literature. The election of a democratic government provides the first step in the dissolution of the old autocratic regime and the

Dr. Judith Hoffmann received her PhD in political science from Free University Berlin, Germany. After working as an international consultant in Albania, she was lecturer in the Euro/Transatlantic Masters program of the Berlin Graduate School of Social Sciences at Humboldt University in Berlin. Currently, she works for the German development cooperation in the Balkans, the Caucasus and in Africa. This article has successfully undergone a double-blind peerreview process. It reflects the opinion of the author only. beginning of the democratization process. As such, elections in the post-socialist transition countries received high attention by the international community, especially, the European Union and the OSCE. Free and fair elections have been part of the EU's political conditionality for the integration of SEE countries since the middle of the 1990s. They were explicitly spelled out as part of the EU's regional concept for SEE in 1997 aiming at stability and economic development. Starting from the late 1990s onwards, free and fair elections became a major EU criterion for advancing its relation with the region, which ultimately led to an integration perspective being offered at the EU Feira Summit in 2000.

The paper takes the case of Albania, a country that has been highly dependent on international support from 1991 onwards, starting its transition as the most isolated and the poorest country in SEE. It thus presents a crucial case in order to explore the absorption of international norms into the domestic system. Since the early 1990s, when Albania's transition process started, the country saw many changes in its political and economic system. The first years were rather rocky and marked by serious setbacks caused by a major state crisis after the collapse of the pyramid schemes in 1997 and the Kosovo crisis, which posed a serious risk to stability in the region and for Europe. Since then, many steps have been taken in bringing Albania closer to a democracy and market economy. Intriguing in the case of Albania is that even though we can observe considerable reform measures being taken towards the 
establishment of a formal democratic political system, Albania struggled and still struggles with holding elections according to international standards - despite great support by the international community and continuous high demands for complying with international standards, in particular by the EU and the OSCE. On the contrary, even though the conduct of proper elections is a fundamental criterion of democracy, the electoral reforms belong to one of the most contended and contested areas of the political system in Albania, especially by the two major political parties, the Democratic Party (DP) and the Socialist Party (SP). Thus, 20 years after the start of transition, the domestic environment in Albania still poses considerable challenges for the Europeanization of political norms and institutions.

The paper focuses on the transformation of the electoral system in Albania as a result of both domestic political process and external conditionality of international actors. It argues that domestic political elites have strategically incorporated international norms into their own political agendas. By constantly contesting the electoral system, they instrumentalised the electoral reform with the aim of getting control over state resources without consolidating democratic structures. In a political environment that is polarized according to the "winner takes it all" logic, elections became a key mechanism of political parties' clientelism. Clientelism is understood here as a "certain mode of managing power relations and manipulation of state institutions in the interest of the people in power, structuring the system around informal networks of personal relationships based on exchange of favours" (Bogdani/Loughlin 2007: 150). This phenomenon can evolve particularly in the context of weak political, social and economic developments, such as poverty, high unemployment, weak democratic states institutions and mistrust in society, circumstances that prevail in most of the transition countries in SEE (ibid.). In Albania, elections are the most significant way for the winning party to tap public resources using it for patronage purposes and ensuring that its power is maintained. Thus, the case of Albania's electoral reform shows the limits of Europeanization in transforming the institutional environment in the challenging context of SEE.

The paper is organised in three parts. Firstly, it analyses the changing electoral system in Albania since the early 1990s and looks at the disputed electoral reform process, particularly after 1997. Secondly, it elaborates on the international assistance to support the domestic electoral reform efforts aimed at stabilizing and consolidating the democratic system. Thirdly, it explores how domestic actors incorporated international norms into their domestic strategies by looking at two crucial elements of the electoral process, voter registration and vote splitting.

\section{Contested Parliamentary Elections and Electoral Reform in Albania}

Throughout the last two decades the Albanian electoral system was changed three times, influencing the number of seats in the parliament as well as the balance between single-member districts and proportional representation: from a majoritarian system applied at the first parliamentary elections in 1991 to a mixed electoral system during 1992-2005, and finally to a regional proportional system in 2008 (Elbasani 2008, SchmidtNeke 2002). The first elections in 1991 were held under a pure majoritarian system. The Labor Party of Albania (later named the Socialist Party of Albania) won 56 percent of the votes and 169 seats (68 percent) out of a 250 -member single-chamber parliament. Before conducting the parliamentary elections in 1992, negotiations for a new electoral code were conducted with the newly born Democratic forces. As a result, a mixed electoral system was adopted. ${ }^{1}$ "The mixed election system had an element of proportionality that attempted to allocate mandates in proportion to a political party's or coalitions' national share of the valid votes." (European Commission for Democracy through Law 2009: 5). The principle of proportionality was laid down in the Albanian Constitution (paragraph. 2, Art. 64). The elections in 1992 conducted under the new mixed electoral system brought the DP into power. While the basic principles of the mixed electoral system were part of the 1998 Constitution (Art. 64), the electoral code has been frequently amended since then and remained the centre of disputes in subsequent years (Hoffmann 2008). Especially between the two major parties, DP and SP, many controversies and conflicts evolved around electoral reforms, for instance on the composition of the Central Election Commission, the boundaries of electoral constituencies, and the voters list. The third change was finally undertaken in 2008, when a new electoral system was approved based on amendments to the Albanian Constitutions adopted on April 21, 2008 (European Commission for Democracy through Law 2009). Instead of the mixed electoral system a regional proportional system based on regional constituencies was introduced.

With the exception of the 1992 elections, parliamentary elections in Albania were criticized by international and national observers and contested by the respective opposition party for not (fully) complying with international standards of democratic elections (Kajsiu et al. 2002, OSCE/ODIHR 1997, 2005, 2009). The 1996 elections were strongly criticized for being characterized by intimidation and fraud in favour of the ruling party DP (Hensell 2009). ${ }^{2}$ After the collapse of the pyramid schemes and the state crisis in 1997 international pressure led to new elections. They were seen as an important way to restore security and order in Albania by the international community. ${ }^{3}$ While the 1997 parliamentary elections were regarded as "acceptable given the prevailing circumstances," the elections in 2001 were internationally criticized for serious irregularities (OSCE/ODIHR 1997: 4, 2001). The 2005 elections were accepted as being largely fair and free even though numerous shortcomings prevailed and international standards were not fully met. For the elections in 2009, the international observers reported improvements ("tangible progress") over previous elections, but noted that they have

1 The mixed electoral system combined a majority and a proportional allocation. Out of 140 members in the parliament 100 were elected directly in single-member electoral zones, while 40 were elected from party lists. Voters had to cast two votes, one vote for single-member districts and one vote for the party lists.

2 The DP obtained with 56 percent of the votes 122 out of 140 seats.

3 The SP won those elections with 53 percent of the votes. 
been "overshadowed by the politicization of technical aspects of the election process" (OSCE/ODIHR 2009: 1).

All parliamentary elections after 1996 were marked by a polarized political culture with deep antagonisms between political forces grouped around the dominant SP and DP (Kajsiu et al. 2002, OSCE/ODIHR 1997, 2001, 2005, 2009). Starting from 1996 , boycotts of the parliament have evolved as a political instrument by the respective political opposition, which was used after each general election (with the exception of 2005) (Commission of the European Communities 2002, Council of Europe 2000). Among the reasons for boycotts was (in most cases) the opposition party's accusation of electoral fraud and manipulations, which resulted in the non-recognition of election results. This reaction presents another feature of the struggle over elections (Schmidt-Neke 1998, 2002). Regardless of the degree of fraud and manipulation or the international concerns raised, the respective opposition parties challenged the electoral results. The most recent example was the stalemate of the political process in 2009 and 2010, when the opposition party SP boycotted the parliament, asking for a thorough investigation into the June 28, 2009 elections, which they claimed were manipulated.

Thus, parliamentary boycotts became a feature of the political process, employed independently from the political orientation by either one of the two major parties as the following table shows:

Table 1: Parliamentary boycotts in Albania since $1996^{4}$

\begin{tabular}{|l|l|}
\hline Government term & Boycott by the opposition party \\
\hline $\begin{array}{l}\text { 1996-1997 DP-led } \\
\text { government }\end{array}$ & September - November 1996 (SP) \\
\hline $\begin{array}{l}\text { 1997-2001 SP-led } \\
\text { government }\end{array}$ & $\begin{array}{l}\text { September 1997 - März 1998 (DP) } \\
\text { Juli 1998 - Juli 1999 (DP) }\end{array}$ \\
\hline $\begin{array}{l}\text { 2001-2005 SP-led } \\
\text { government }\end{array}$ & Juni 2001 - Januar 2002 (DP) \\
\hline $\begin{array}{l}\text { Since 2009 DP-led } \\
\text { government }\end{array}$ & September 2009 - February 2010 (SP) \\
\hline
\end{tabular}

Party rivalry with high tensions between the two major parties before as well as after elections prevailed throughout the $1990 \mathrm{~s}$ and the 2000s (Hoffmann 2008, International Crisis Group 2001). It showed that there was little interest in a consensusoriented approach to find common solutions and creating majorities for political policy options. Most of the controversies were not content-related, i.e. concerning specific policies, but were structured along a "friend-enemy" division. ${ }^{6}$ The OSCE concluded after the 2001 elections that the "major political parties continued to treat each other as enemies, rather than as legitimate political opponents." (OSCE/ODIHR 2001: 2)

4 Hoffmann (2008); http://www.setimes.com/cocoon/setimes/xhtml/en_GB/ newsbriefs/setimes/news-briefs/ 2010/05/17/nb-08 (Accessed: 17.05.2010).

5 After February 2010, the SP continued a partial boycott, voting on only some laws in which it had a specific interest.

6 The programmes of both major parties for the 2009 elections differed only slightly (OSCE Presence in Albania 2009).
This nature of the controversies is further enhanced by the way most voters relate to political leaders and "demand" privileges as a reward for their loyalty. Voters' electoral choices are mostly motivated by the personalities of the party leaders or local loyalties rather than by party programmes or political agendas because of perceived benefits to be offered to faithful party members through clientelist practices (Bogdani/Loughlin 2007, Gërxhani/Schram 2000, Ilirjani 2005). Voters' expectations to receive rewards once their MPs are voted into the parliament are high. This type of patron-client relationship works for all parties. While in urban areas citizens expect first of all employment opportunities as a benefit after the elections, rural voters expect mostly benefits in the form of funds allocated to the region, e.g. provision of better infrastructure. In sum, voterparty alignment is still shaped to a high degree by clientelist relations (Hensell 2009, Rakipi 2007, 2008).

Distribution of public resources (e.g. awarding public contracts, granting licences) is thus an important means of voter mobilization. There are strong indications that the respective Albanian governments have used the provision of employment as well as public resources to influence the results of the elections and favour their clientele respectively (Bogdani/Loughlin 2007, Kajsiu et al. 2002, OSCE/ODIHR 2009). Politically motivated turnover in the public administration after elections or recruitment before elections, which circumvent the civil service law, has been a point of continuous criticism by the EU. "Recruitment in the civil service continues to take place through non-transparent procedures." (Commission of the European Communities 2009: 10) During the last electoral campaign in 2009, both DP and - less frequently - the SP used official events (including inaugurations of infrastructure projects) for campaign purposes, "blurring the distinction between state and party." (ibid.: 2) As well, "there were substantiated allegations of misuse of administrative resources by the DP for campaign purposes." (ibid.) In sum, elections became a central "battle field" between the two major parties within the clientelist political structure with the ultimate objective to control state resources.

\section{International Assistance to Electoral Reform: Transferring International Norms}

International assistance to electoral reform in Albania was provided by various international organisations, in particular by the OSCE since the establishment of its presence in Albania in 1997. Additionally, the EU closely monitored the elections in Albania. After the opening of the negotiations for a Stabilisation and Association Agreement (SAA) in 2003, the EU reported regularly on progress towards meeting the political Copenhagen criterion, including elections.

Since 1997, the OSCE observed the electoral reform process and supported negotiations between the political parties to establish and amend the electoral code according to recommendations provided by the OSCE/ODIHR election observation reports. After the Albanian Constitution was adopted in 1998, laying down the basic principles of the mixed electoral system (Art. 64), the electoral code was amended 
several times. Following the contested parliamentary elections in 1997, the OSCE presence in Albania accompanied closely the discussions in a bipartisan working group drafting an electoral code based on international standards. The new electoral code was adopted on May 8, 2000 as Law No. 8609. By providing a legal and administrative framework for conducting democratic elections, a considerable adoption of the code to international standards was achieved.

After the parliamentary elections in 2001, internationally criticized for serious irregularities, a bipartisan parliamentary committee on electoral reform was again created upon a recommendation by OSCE/ODIHR. ${ }^{7}$ During its mandate from May 2002 to March 2003, the OSCE assisted the implementation of the various recommendations by OSCE/ODIHR and the Council of Europe. After difficult negotiations, the committee finally agreed on technical improvements of the electoral code, among others the voter lists and the administrative procedures for electoral complaints and appeals (Hoffmann 2008). The amended electoral code was adopted in the parliament on June 19, 2003 as Law No. 9087.

After the local elections in October 2003, conducted under the new electoral code, OSCE/ODIHR monitoring concluded that further revisions of the electoral code were necessary, given that central aspects of the elections (e.g. the composition of the central election commission and the voter registration) were not improved in relation to the 2001 elections. Another bipartisan parliamentary committee worked between July and October 2004 on the recommendations of OSCE/ODIHR. However, reaching agreement on changes to the electoral code was very difficult, and the conflict between the two major parties could only be solved with the assistance of the international community, most prominently the OSCE. The amendments to the electoral code were finally adopted by the parliament in October 2004. Further amendments (e.g. concerning a new definition of the 100 electoral districts) were made in January and April 2005, only shortly before the parliamentary elections in July 2005. According to the former ambassador of the OSCE Presence in Albania, Pavel Vacek, the biggest problem during this process was "the lack of political will" to quickly reach an agreement (ibid.). The elections in 2005 were accepted as being largely fair and free even though numerous shortcomings prevailed and international standards were not fully met. In 2008, the electoral code was once again revised to address several recommendations by OSCE/ODIHR. With the latest reform, Albania shifted from a mixed electoral system to a purely proportional system. For the elections in 2009 , the international observers reported tangible progress in comparison to previous elections, even though they were concerned by the politicization of technical aspects of the electoral process (OSCE/ODIHR 2009).

Until 2001, problems connected to conducting democratic elections according to international standards were regarded by the OSCE as "technical issues" that require some formal changes in the electoral code and the electoral process (e.g. to improve the civil registry to provide a correct voters list). However,

7 It was co-chaired by the SP and DP with representation from all parties represented in the parliament. after several recommendations had not led to substantive improvements in the electoral process, OSCE/ODIHR started in 2001 to explicitly mention in its observation reports that the failure to fulfil international standards were not related to a lack of capacities but a lack of a political will of the Albanian political elites to conduct democratic elections (OSCE/ODIHR 2001). Similar statements were made after the 2005 elections, when it criticized that "the major political parties are yet to demonstrate political will (...). This was particularly evident in the parties' approach to the election administration, the full respect for citizens' fundamental freedoms, and the implementation of electoral strategies to maximise electoral gains." (OSCE/ODIHR 2005: 1) ${ }^{8}$

This conclusion contrasts to the rather positive view of the 2005 elections by the EU. The EU saw those elections as an important test for the functioning of democracy in Albania. After slow reform progress in 2003 and 2004, the EU stressed that Albania would need to ensure a proper conduct of the 2005 elections as well as progress regarding the European Partnership priorities before the SAA could be concluded. "If the next elections will be again problematic, this will be a serious setback in the aspiration of the country to make progress on its way towards European integration." (Delegation of the European Commission in Albania, press release of 24 February 2005) The postponement of the SAA conclusion until after the elections was thus seen as an incentive for the Albanian government to undertake stronger reform efforts. In its 2005 progress report the EU concluded that "(d)espite shortcomings, these parliamentary elections were fundamentally valid and led to a smooth change of government." (European Commission 2005: 66) The EU took the peaceful transfer of power from the SP to the winning DP, the improvement of the overall political situation as well as some progress in various reform areas (e.g. approximation to European standards) undertaken by the new government as a positive sign. ${ }^{9}$ It also stressed - as in previous progress reports - the constructive attitude of Albania towards its regional neighbours, which contributed to stability in the region. As a result, the European Commission recommended the conclusion of the SAA with Albania which was signed on June 12, 2006. This was celebrated by the DP government as its major political success. ${ }^{10}$ Nonetheless, the EU stressed in its 2005 progress report that visible progress in important reform areas was necessary, among them the continuation of electoral reform. While during the 2009 parliamentary elections most OSCE commitments were met, Albania did not realise its potential to "adhere to the highest standards for democratic elections," e.g. because of the politicisation of the vote count (European Commission 2009: 6).

Despite strong and continuous international support, in some crucial areas of the electoral process, like voter registration, shortcomings were not properly addressed by the respective Albanian governments, and major issues around the electoral process were not changed for several years. In the following,

8 This included technical and administrative problems, related to tactical voting and a need to further improve voter lists (European Commission 2005).

9 According to EU Enlargement Commissioner Olli Rehn: "given the largely free and fair general elections earlier this month, Albania has removed a critical barrier" to the SAA conclusion" (Albanian News, 13.7.2005).

10 It entered into force on April 1, 2009. 
two cases will briefly be looked at: the incomplete registration of voters and the misuse of vote splitting under the mixed electoral system.

\section{Incorporating International Norms into Domestic Actors' Strategies}

The problem of the incomplete voter registration - and thus faulty voter lists - was already criticized by the international community after the 1997 elections (OSCE/ODIHR 1997). After the 2001 parliamentary elections, the government was urged to undertake considerable efforts to overcome this problem. Subsequently, the election administration (including the civil registry and the voter lists) was part of the bipartisan parliamentary committee's discussion to reform the electoral code between May 2002 and March 2003. However, after the 2003 local elections ODIHR highlighted that the incomplete and faulty voter lists were a persistent problem that had not been resolved despite international assistance (Hoffman 2008). Again, a bipartisan committee worked on steps to improve the voter registration between July and October 2004. In the preparations for the 2005 parliamentary elections the creation of complete voter lists taken from the civil registry were supported by the OSCE and by the European Commission with a grant in the amount of 800.000 EUR (ibid.). However, in their observations of the 2005 parliamentary elections the international community concluded that the elections still had numerous shortcomings, in particular the incomplete voter lists (OSCE/ODIHR 2005). The OSCE stressed that the reason for the inaccurate voter lists was not removed: "The continued inaction of the Albania authorities in introducing a uniform system of addresses of buildings and new personal identification documents across the country diminishes the significance of efforts undertaken to improve the voter lists." (ibid.: 1)

Only in 2008, a computerized National Civil Status Register database was finally completed and used as the source of the voter lists. Furthermore, national personal ID numbers as well as a new personal identity document (a high-level security ID card containing biometric data) were issued to citizens. Both measures had an "important impact on the elections and addressed previous OSCE/ODIHR recommendations" (OSCE/ODIHR 2009: 9). However, looking at these reforms it has to be considered that ensuring document security was a necessary requirement under the roadmap agreement with the European Commission on visa liberalization (ESI 2009). Visa liberalization - and subsequently visa-free travel to the EU - has been an important electoral promise made by both major parties, in particular by Prime Minister Sali Berisha (DP) for many years (Republika e Shqipërisë 2009). Thus, the importance of document security for the visa liberalization process, which was high on the domestic political agenda, was conducive to the realization of the computerized population register, which laid a sound basis for complete voter lists. It took more than 10 years to achieve this crucial step.

The second example where political actors instrumentalised electoral reform for their own purposes was the so-called strategic voting, i.e. the use of vote splitting allowed under the mixed-electoral framework by giving the votes to two different political parties the voter would like to see form a government. ${ }^{11}$ This happened firstly during the 2001 elections when party strategies were applied with the objective to maximise party interest, distorting the constitutional objective of proportionality in the translation of votes into seats. After the 2001 elections, OSCE/ODIHR criticized that parties had tested "the law beyond acceptable limits" (OSCE/ODIHR 2001: 2). During the 2005 elections, "strategic voting" reached widescale use and was used by both major parties and their small allies. As a result, there was a considerable difference between the percentages of mandates in comparison to the percentages of national votes: the DP received 32 percent more seats than votes while the SP received 21 percent more seats than votes (OSCE/ODIHR 2005). Following the elections, OSCE/ODIHR concluded that "both major political camps based their campaigns, in part, on electoral strategies that (...) blurred distinctions between political parties and had the potential to circumvent the objective of proportionality "to the closest possible extent'" (OSCE/ODIHR 2005: 13). Addressing several recommendations by OSCE/ODIHR after the 2005 elections, the electoral code was once again revised, abolishing the mixed electoral system and introducing the regional proportional electoral system.

Experts warn that no miracles can be expected from a change of the electoral system as the application of the electoral code and the implementation of the electoral system in a specific country context is crucial (Elbasani 2008). However, the new electoral code adopted in 2008 was expected to facilitate the electoral procedures and voter administration, particularly vote counting and calculation of results as citizens only cast one vote (OSCE/ODIHR 2009). This time (2008) the consensus was not mediated by the OSCE but could be reached because both major parties had a strong interest in the reform. Thus, inter-party compromise was found, among others concerning constitutional amendments necessary to change the electoral system, although smaller parties protested against the adoption of the new electoral code. "The two largest parties dominated the reform agenda and the outcome is seen to benefit them." (NDI 2009: 2) Looking at the 2009 parliamentary results, it can be concluded that the new electoral system "greatly favoured the two biggest parties over smaller parties vying for seats in parliament." (Korenica and Doli 2009) According to international election observers, the new code "brought about significant improvements" (ibid.: 1). Nonetheless, in a quarter of the ballot counting centers, the vote counting was assessed bad or very bad - even though in general, "there was no evidence of irregular counting or manipulation of results" (ibid.: 4). However, the opposition party SP did not accept the narrow electoral victory of the DP and started to boycott the parliament in September 2009 until February 2010, accusing the DP of electoral fraud and manipulation. ${ }^{12}$ Both examples show that the late adoption of change measures as well as the misuse of formally democratic legal provisions was primarily a deliberate action of both major parties.

11 This way, smaller parties receive more votes in the proportional part of the election.

12 The DP and its allies won 68 seats ( 46.92 per cent), the SP won 66 seats ( 45.34 per cent). 


\section{Conclusion}

The paper looked at a challenging domestic environment for Europeanization, focusing on electoral reforms in Albania. Free and fair elections have been part of the EU's political conditionality for the integration of Southeast European countries since the middle of the 1990s. However, even though electoral reform remained high on the political agenda in Albania for more than a decade, progress in accomplishing fair and free elections was only partly achieved. Analysing the parliamentary elections in Albania, it was shown that the frequent change of the electoral code did not lead to a "linear improvement" of the electoral process as expected by the international community. It was rather the succession of new rounds of political power struggles between the main political parties, SP and DP, over influencing the chances to win the next parliamentary elections. Furthermore, it was shown that the contestation of elections as well as subsequently the dispute about electoral reform is the manifestation of the prevailing rationale of the domestic political actors shaped by clientelism. Their logic follows the objective of 'owning' the state as the most significant way to get access to public resources, which can be distributed as privileges to the respective party's clientele in order to secure one's own political power. Thus, the contestation of electoral results as well as the electoral reform was instrumental for the major political parties following their ultimate goal to get control of the state serving their patronage purposes.

The case of electoral reform in Albania thus challenged the assumption of the successful role EU conditionality has played in transforming post-socialist socities in the region. It showed that we cannot assume a uniform 'incorporation' of European norms and institutions into the domestic political systems of SEE. Domestic elites rather adopted the international norms according to their own political rationale. Even if they apparently made institutional changes according to European norms, it does not necessarily mean that these institutions function the way they do in a European context. Rather, they might serve to support the existing domestic power system. The case of Albania's electoral reform thus showed the limits of Europeanization in transforming the institutional environment in the challenging context of SEE.

\section{Literature}

Albanian Constitution 1998. Approved by the parliament, 21 October 1998, Tirana. http://www.president.al/english/pub/ doc/Albanian\%20Constitution.pdf (access: 05.02.2011).

Bogdani, Mirela and Loughlin, John 2007. Albania and the European Union. London, New York.

Commission of the European Communities 2002. Albania. Stabilisation and Association Report, Commission Staff Working Paper. COM 163. Brussels.

Commission of the European Communities 2009. Albania 2009 Progress Report. Commission Staff Working Document. SEC(2009) 1337/3. Brussels.
Council of Europe 2000. Honouring of obligations and commitments by Albania. Parliamentary Assembly. Doc. 8771. 14 June 2000.

Delegation der Europan Commission in Albania 2005. Press release of 24 February 2005.

Elbasani, Arolda 2008. Mixed Member Proportional Systems and Post-Communist Contexts: How Has the System Worked in Albania? CEU Political Science Journal 3 (1): 72-92.

Elbasani, Arolda 2011 (ed.). EU Enlargement and Europeanization in the Western Balkans. London and New York: Routledge (forthcoming).

European Stability Initiative (ESI) 2009. Scorecard - Schengen White List Conditions.

European Commission 2005. Albania. 2005 Progress Report, COM (2005) 561 final, Brussels. http://ec.europa.eu/enlargement/ archives/pdf/key_documents/2005/package/sec_1421_final_ progress_report_al_en.pdf (access: 05.02.2011).

European Commission for Democracy through Law 2009. Joint Opinion on the Electoral Code of the Republic of Albania, Strasbourg/Warsaw.

Featherstone, Kevin and Radaelli, Claudio M. 2003. The Politics of Europeanization. Oxford University Press.

Gërxhani, Klarita and Schram, Arthur 2000. Albanian PoliticalEconomics: Consequences of a Clan Culture, LICOS Discussion Paper 92/2000.

Grabbe, Heather 2001. How does Europeanization affect CEE governance? Conditionality, diffusion and diversity, Journal of European Public Policy, 8(6), pp. 1013-1031.

Grabbe, Heather 2003. Europeanization Goes East: Power and Uncertainty in the EU Accession Process. Featherstone, Kevin and Radaelli, Claudio M. (eds). The Politics of Europeanization. Oxford University Press.

Hensell, Stephan 2009. Die Willkür des Staates: Herrschaft und Verwaltung in Osteuropa. Wiesbaden.

Hoffmann, Judith 2008. Die Integration Südosteuropas. Die Demokratisierungspolitik europäischer Organisationen in Albanien, Baden-Baden.

Ilirjani, Altin 2005. Political Choice in Albania. The 2005 Albanian Parliamentary Elections. Albanian Journal of Politics, I (1): 75-86.

International Crisis Group (ICG) 2001. Balkans Briefing. Albania's Parliamentary Elections 2001.

Kajsiu, Blendi/ Bumci, Aldo and Rakipi, Albert 2002. Albania. A Weak Democracy and a Weak State. Albanian Institute for International Studies. Tirana.

Korenica, Fisnik and Doli, Dren 2009. Election Briefing No. 56. Europe and the Albanian Parliamentary Elections. European Parties Elections and Referendums Network.

National Democratic Institute (NDI) 2009. Albania's Elections and the Challenge of Democratic Transition. U.S. Congressional Commission on Security and Cooperation in Europe Briefing, June 4, 2009. 
Misha, Maklen/ Rakipi, Albert 2010. The European Perspective of Albania. Albanian Institute for International Studies, Tirana.

OSCE Presence in Albania 2009. Press Review Extra No. 315. Translation of a Shqip Article on the four party programmes from the main election coalitions, Tuesday 17 June 2009.

OSCE/ODIHR 1997. Albania Parliamentary Elections, June 29, 1997. OSCE/ODIHR Election Observation.

OSCE/ODIHR 2000. Republic of Albania. Local Government Elections, Warsaw.

OSCE/ODIHR 2001. Republic of Albania. Parliamentary Elections. 24 June - 19 August 2001, 11 October 2001, Warsaw.

OSCE/ODIHR 2005. Republic of Albania. Parliamentary Elections, 3 July 2005, OSCE/ODIHR Elections Observation Mission Report. Warsaw.

OSCE/ODIHR 2009. Republic of Albania. Parliamentary Elections, June 28 2009, OSCE/ODIHR Elections Observation Mission Final Report. Warsaw.

Radaelli, Claudio M. and Pasquier, Romain 2008. "Conceptual Issues". In: Vink, Maarten P. and Graziano, Paolo (2008). Europeanization - New Research Agendas. Basingstoke: Palgrave Macmillan.

Rakipi, Albert 2007 (ed.). Strengthening Internal Party Democracy in Albania. Albanian Institute for International Studies, Tirana.

Rakipi, Albert 2008 (ed.). Albania and the European Union. Rethinking EU Integration. Albanian Institute for International Studies, Tirana.

Rakipi, Albert 2008. Weak States and Security. Rethinking the Balkan Post-Cold War Security Agenda. Albanian Institute for International Studies, Tirana.

Republika e Shqipërisë. Këshilli i Ministrave Departamenti $i$ Informacionit 2009. Address of Premier Berisha during presentation of governing program in Parliament, 16.09.2009.

Schimmelfennig, Frank and Ulrich Sedelmeier 2002. Theorizing EU enlargement: Reserach Focus, Hypothesis, and the State of Research, in: Journal of Public Policy 9 (4), pp. 500-528.

Schimmelfennig, Frank and Ulrich Sedelmeier 2005. The Europeanization of Central and Eastern Europe. Cornell University Press: Ithaca, NY.

Schimmelfennig, Frank and Sedelmeier, Ulrich 2008. "Candidate Countries and Conditionality. In: Vink, Maarten P. and Graziano, Paolo (ed.). Europeanization - New Research Agendas. Basingstoke: Palgrave Macmillan.

Schmidt-Neke, Michael 1998. Regierungswechsel in Albanien. Die Rückkehr der Krise. Südosteuropa 47 (10-11): 516-535.

Schmidt-Neke, Michael 2002. Das politische System Albaniens. Ismayr, Wolfgang (ed.). Die politischen Systeme Osteuropas. Opladen: 767-805.

\section{Führend in der IB-Forschung}

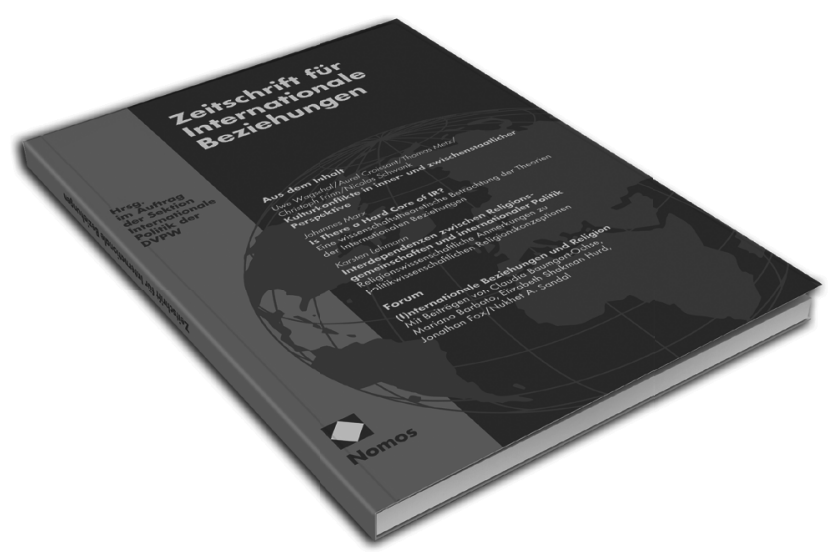

Zeitschrift für Internationale Beziehungen (ZIB)

18. Jahrgang 2011, erscheint $2 \times$ jährlich

ISSN $0946-7165$

Jahresabo: $79,-€^{*}$

Gesamtpreis: 87,03€

Vorzugspreis für Mitglieder der DVPW: 70,- $€^{*}$

(bitte Bescheinigung zusenden) Gesamtpreis: 78,03€

Vorzugspreis für Studierende: 46,-€ *

(bitte Bescheinigung zusenden) Gesamtpreis: 54,03 $€$

Jahresabo mit Online-Zugang: 95,-€ *

(nur Privatbezieher) Gesamtpreis: 103,03€

*inkl. MwSt. zzgl. Vertriebskosten (€ 8,03/Jahr) (Porto/Inland € 6,42

+ Direktbeorderungsgeb. $€ 1,61)$

In der Zeitschrift für Internationale Beziehungen (ZIB) werden vor allem methodisch reflektierte und theoretisch interessierte Auseinandersetzungen mit Fragestellungen der Internationalen Beziehungen (IB) veröffentlicht.

Außerdem informieren in der ZIB publizierte Literaturberichte über die Diskussionen in wichtigen Forschungsfeldern der IB. Die ZIB bildet inzwischen das führende deutschsprachige Kommunikationsforum für die politikwissenschaftliche Analyse internationaler Politik. Mit ihrem spezifischen Profil in der Verknüpfung von Theorie und Empirie sowie durch herausragende Beiträge genießt sie weithin Beachtung.

Die Zeitschrift für Internationale Beziehungen wendet sich an Politik- und Medienwissenschaftler sowie an alle an Weltpolitik und Internationalen Beziehungen Interessierte.

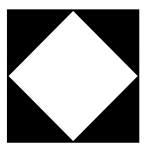

Nomos

Bitte bestellen Sie im Buchhandel oder versandkostenfrei unter $\downarrow$ www.nomos-shop.de 